Journal of Anatolian Environmental and Animal Sciences (Anadolu Çevre ve Hayvanculık Bilimleri Dergisi)

DOI: https://doi.org/10.35229/jaes.714366
JAES

Year: 5, No: 2, $2020(212-217)$

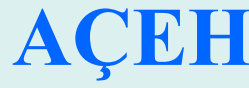

Y1l: 5, Sayı: 2, $2020(212-217)$

\title{
Determination of Reference Values of Some Hematological and Immunological Parameters in Healthy Russian Sturgeon (Acipenser gueldenstaedtii)
}

\author{
Selçuk DUMAN* \\ Department of Aquaculture, Imamoglu Vocational School, Cukurova University, Adana/TURKEY
}

How to cite: Duman. S. (2020). Determination of Reference Values of Some Hematological and Immunological Parameters in Healthy Russian Sturgeon (Acipenser gueldenstaedtii). J. Anatolian Env. and Anim. Sciences, 5(2), 212-217.

Atıf yapmak için: Duman. S.. (2020). Sağlıklı Rus Mersin Balıklarında (Acipenser gueldenstaedtii) Bazı Hematolojik ve İmmünolojik Parametrelerin Referans Değerlerinin Belirlenmesi. Anadolu Çev. ve Hay. Dergisi, 5(2), 212-217.

: https://orcid.org/0000-0002-6771-3385

*Corresponding author's:

Selçuk DUMAN

Department of Aquaculture, Imamoglu

Vocational School, Cukurova University,

Adana/TURKEY

$\triangle$ : sduman@cu.edu.tr

Mobile telephone : +90 (507) 4062158

Fax : $+90(322) 3386539$

\begin{abstract}
This study aims to determine the reference intervals of some hematological and immunological parameters in healthy Russian sturgeon (Acipenser gueldenstaedtii Brandt \& Ratzeburg, 1833) blood. These parameters are important indicators of fish physiological status and fish health. In the study, reference ranges of erythrocyte, leukocyte, lymphocyte, monocyte, eosinophil, neutrophil, basophil, and hematocrit values were determined for hematological parameters. In terms of immunological parameters, the reference intervals of TNF- $\alpha$ (tumor necrosis factor-alpha), IFN- $\gamma$ (interferon-gamma), IL-1 $\beta$ (interleukin 1 beta), IL-6 (interleukin 6 ) and IL-8 (interleukin 8) values were determined. The reference ranges we have detected; erythrocyte $0.77-1.23 \times 10^{6} / \mathrm{mm}^{3}$, leukocyte $9.21-16.96 \times 10^{3} / \mathrm{mm}^{3}$, lymphocyte $43.35-59.78 \%$, monocyte $4.61-11.39 \%$, eosinophil $3.27-6.52 \%$, neutrophil $12.16-18.41 \%$, hematocrit 22.14 $28.63 \%$, TNF- $\alpha$ 27.59-49.83 pg/ml, IFN- $\gamma$ 66.25-79.34 pg/ml, IL-1 $\beta$ 1.08-1.76 pg/ml, IL-6 $11.2-19.7 \mathrm{pg} / \mathrm{ml}$ and IL-8 $31.4-52.7 \mathrm{pg} / \mathrm{ml}$. It is thought that the hematological and immunological reference intervals detected in the Russian sturgeons which will contribute significantly to the determination of the health and physiological situation of these fish.
\end{abstract}

Keywords: Acipenser gueldenstaedtii, hematology, immunology, sturgeon.

\section{Sağlıklı Rus Mersin Balıklarında (Acipenser gueldenstaedtii) Bazı Hematolojik ve İmmünolojik Parametrelerin Referans Değerlerinin Belirlenmesi}

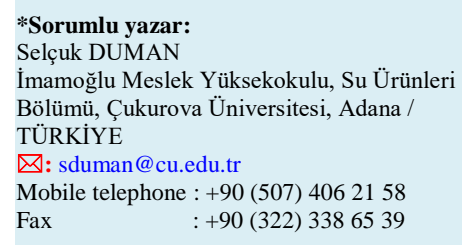

Öz: Bu çalışmanın amacı, sağlıklı Rus mersin balığı (Acipenser gueldenstaedtii Brandt \& Ratzeburg, 1833) kanında bazı hematolojik ve immünolojik parametrelerin referans aralıklarını belirlemektir. $\mathrm{Bu}$ parametreler balığın fizyolojik durumu ve balık sağlığının önemli göstergeleridir. Çalışmada, hematolojik parametreler için eritrosit, lökosit, lenfosit, monosit, eozinofil, nötrofil, bazofil ve hematokrit değerleri referans aralıkları belirlenmiştir. İmmünolojik parametreler açısından ise, TNF- $\alpha$ (tümör nekroz faktör alfa), IFN- $\gamma$ (interferon gama), IL-1 $\beta$ (interlökin 1 beta), IL-6 (interlökin 6) ve IL-8 (interlökin 8) referans aralıkları belirlenmiştir. Belirlediğimiz referans aralıkları; eritrosit $0,77-1,23 \times 10^{6} / \mathrm{mm}^{3}$, lökosit \% 9,21-16,96 $\times$ $10^{3} / \mathrm{mm}^{3}$, lenfosit $\% 43,35-59,78$, monosit \% 4,61-11,39, eozinofil \% 3,27-6,52, nötrofil \% $12,16-18,41$, hematocrit \% 22,14-28,63, TNF- $\alpha 27,59-49,83 \mathrm{pg} / \mathrm{ml}$, IFN- $\gamma \quad 66,25-79,34 \mathrm{pg} / \mathrm{ml}$, IL-1 $\beta$ 1,08-1.76 pg/ml, IL-6 11,2-19,7 pg/ml ve IL-8 31,4-52,7 pg/ml. Rus mersin balıklarında tespit edilen hematolojik ve immünolojik referans aralıklarının, bu balıkların sağlık ve fizyolojik durumlarının belirlenmesine önemli katkı sağlayacağı düşünülmektedir.

Anahtar kelimeler: Acipenser gueldenstaedtii, hematoloji, immünoloji, mersin balığı. 


\section{INTRODUCTION}

Sturgeon, whose evolutionary past goes back 100 million years ago, is the anadrome and potamodromous species located in the northern hemisphere region (Bahmani, 1998; Tavakoli et al., 2019). Wild sturgeon populations have decreased significantly due to factors such as urbanization, dams preventing migration routes, overfishing and water pollution. The Russian sturgeon (Acipenser gueldenstaedtii, also known as diamond or Danube sturgeon) has recently been among the important species in sturgeon aquaculture applications (Duman, 2019a). Sturgeon is famous for its caviar obtained from the mature but unfertilized eggs of the female fish from a biological point of view, and it is also a valuable fish in terms of meat as they are large-bodied. Therefore, sturgeon culture is increasing rapidly in the world and Turkey (Duman, 2019b). Research for sturgeon has generally focused on protection biology, ecology, and reproduction areas, while less effort has been spent on sturgeon physiology (Baker et al., 2005). Blood is an accessible component in the body fluid system and is examined to assess the physiological state of the creature (Houston \& Carlile, 1997). Hematological studies are accepted as one of the important biological features in aquaculture (Bahmani, 1999). Hematological parameters have a significant act in detecting the physiological response of fish to environmental conditions, also these parameters are between the most important indicators of pesticides, metals and toxic compounds for living creatures in aquatic environments (Van Vuren, 1986; Nussey et al., 1995). Cytokines are infection inhibitors that play an act in natural immunity and the development of hematopoietic cells, they also stimulate the immune function of cells (Duman \& Şahan, 2018). In sturgeon breeding, it is important to examine the quantitative properties in the blood as it provides a reliable index of physiological conditions, especially in the development of fish (Alyakrinskaya \& Dolgova, 1984). In the monitoring of the impact of physiological or sublethal stress caused by exogenous or endogenous changes in fish, changes of some blood parameters are used often (Cataldi et al., 1998). In sturgeon breeding, it is becoming increasingly important to evolve new methods to exactly determine the health of the fish during the production cycles and to diagnose diseases early. Changes in hematological and immunological values are frequently indicative of changes in physiological status and are used routinely to determine the health of domestic and wild animals, but it cannot be used due to the lack of reference ranges in many fish species, with the inclusion of sturgeon (Knowles et al., 2006).

This study aim is to determine the reference ranges of some hematological and immunological parameters such as erythrocyte, leukocyte, lymphocyte, monocyte, eosinophil, neutrophil, hematocrit, IFN- $\gamma$, TNF$\alpha$, IL-1 $\beta$, IL-6 and IL- 8 in healthy Russian sturgeon (Acipenser gueldenstaedtii Brandt \& Ratzeburg, 1833).

\section{MATERIAL AND METHOD}

The research was carried out in a commercial fish farm that breeding Russian sturgeon (Acipenser gueldenstaedtii) in the city of Adana in Turkey. In this study, the principles of the local ethics committee were complied with. The fish with an average weight of $3670 \pm 295.2 \mathrm{~g}$ and a mean length of $82.4 \pm 9.3 \mathrm{~cm}$ were stocked in three concrete ponds (30 fish/pond, stocking density $\left.13.7 \pm 0.52 \mathrm{~kg} / \mathrm{m}^{2}, \mathrm{n}=90\right)$. Supplied water flow rate for concrete ponds was $14 \mathrm{~L} \mathrm{~min}^{-1}$ and ponds dimension was $2 \times 4 \times 1 \mathrm{~m}$. The fish were subjected to macroscopic (external examination by the eye) and microscopic (parasitological and bacteriological examination) health screening before being taken into ponds. Also, during the experiment, water temperature, oxygen, and $\mathrm{pH}$ values were measured every morning and evening by using a YSI 6600 CTD multi-parameter. In the trial, sturgeon feed (no: 4.5) was used and fish were fed at $0.75 \%$ of live body weight four times a day (Chebanov \& Galich, 2011). After the two-week adaptation period, the fish were analyzed. The fish were anesthetized with $20 \mathrm{~mL} / \mathrm{L}$ quinaldin sulfate (Şahan et al., 2017) and $2 \mathrm{ml}$ blood was drawn from the caudal vein of each fish using a heparinized syringe for hematological analyzes (Blaxhall \& Daisley, 1973; Trenzado et al., 2003).

Erythrocyte and leucocyte cells were counted using Natt-Herrick solution and Thoma hemocytometer (Kocabatmaz \& Ekingen, 1984). Cyan-methemoglobin and micro-hematocrit methods were used for Hemoglobin and hematocrit values (Kocabatmaz \& Ekingen, 1984; Stolen et al., 1994). Peripheral blood smears were stained with a mixture of May-Grünwald and Giemsa subsequently, the percentage of lymphocyte, monocyte, neutrophil, and eosinophil cell types were identified using a microscope (Blaxhall, 1972; Fujimaki \& Isoda, 1990). Catalog no. MBS702530 fish ELISA Kit for IFN- $\gamma$, catalog no. MBS024441 fish ELISA Kit for TNF- $\alpha$, catalog no. MBS700230 fish ELISA Kit for IL-1 $\beta$, catalog no. MBS702353 fish ELISA Kit for IL-6 and catalog no. MBS700055 fish ELISA Kit for IL-8 were used in the cytokine analyses. In these analyses, the enzyme-linked immunosorbent assay (ELISA) kits were used which suitable for fish and the results of TNF- $\alpha$, IFN- $\gamma$, IL- $1 \beta$, IL6 , and IL- 8 cytokine levels were evaluated based on the principles of the double-antibody sandwich method (Voller et al., 1978). In the statistical analysis of the results, the non-parametric estimation method with the SPSS 
statistical package program was used for the reference interval determination (Düzgüneş et al., 1983).

\section{RESULTS AND DISCUSSION}

In this study with healthy Russian sturgeon (Acipenser gueldenstaedtii), some hematological (such as erythrocyte, leukocyte, lymphocyte, monocyte, eosinophil, neutrophil, hematocrit), and immunological (such as IFN$\gamma$, TNF- $\alpha$, IL-1 $\beta$, IL-6, IL-8) parameter levels were determined. Furthermore, basic data on this subject was created. In terms of hematological parameters, the mean erythrocyte, leukocyte, lymphocyte, monocyte, eosinophil, neutrophil, and hematocrit values were determined as 1.07 $\times 10^{6} / \mathrm{mm}^{3}, 12.09 \times 10^{3} / \mathrm{mm}^{3}, 52.35 \%, 9.17 \%, 4.21 \%$, $16.31 \%$, and $26.48 \%$, respectively. Also, in terms of immunological parameters, the mean IFN- $\gamma$, TNF- $\alpha$, IL- $1 \beta$, IL-6, and IL-8 values were determined as $70.95 \mathrm{pg} / \mathrm{ml}$, $40.26 \mathrm{pg} / \mathrm{ml}, 1.57 \mathrm{pg} / \mathrm{ml}, 16.46 \mathrm{pg} / \mathrm{ml}$ and $44.58 \mathrm{pg} / \mathrm{ml}$, respectively. Reference ranges of hematological analyzes are given in Table-1, also reference ranges of immunological analyzes are given in Table-2. The lowest and highest values of the measured water parameters $\left(\mathrm{O}_{2}\right.$, $\mathrm{pH}$ and temperature) are given in Table 3.

Table 1. Reference intervals of hematological parameters in Russian sturgeon (Acipenser gueldenstaedtii).

\begin{tabular}{lc}
\hline Hematological parameters & Reference intervals \\
\hline Erythrocyte $\left(\times 10^{6} / \mathrm{mm}^{3}\right)$ & $0.77-1.23$ \\
Leukocyte $\left(\times 10^{3} / \mathrm{mm}^{3}\right)$ & $9.21-16.96$ \\
Hematocrit $(\%)$ & $22.14-28.63$ \\
Lymphocyte $(\%)$ & $43.35-59.78$ \\
Monocyte $(\%)$ & $4.61-11.39$ \\
Eosinophil $(\%)$ & $3.27-6.52$ \\
Neutrophil $(\%)$ & $12.16-18.41$ \\
\hline
\end{tabular}

Table 2. Reference intervals of immunological parameters in Russian sturgeon (Acipenser gueldenstaedtii).

\begin{tabular}{lc}
\hline Immunological parameters & Reference intervals \\
\hline TNF- $\alpha(\mathrm{pg} / \mathrm{ml})$ & $27.59-49.83$ \\
IFN- $\gamma(\mathrm{pg} / \mathrm{ml})$ & $66.25-79.34$ \\
IL-1 $\beta(\mathrm{pg} / \mathrm{ml})$ & $1.08-1.76$ \\
IL-6 $(\mathrm{pg} / \mathrm{ml})$ & $11.2-19.7$ \\
IL-8 $(\mathrm{pg} / \mathrm{ml})$ & $31.4-52.7$ \\
\hline
\end{tabular}

Table 3. In the measured water parameters, lowest and highest values of $\mathrm{O}_{2}, \mathrm{pH}$ and water temperature.

\begin{tabular}{lcc}
\hline $\mathbf{O}_{2}(\mathbf{m g} / \mathbf{L})$ & $\mathbf{p H}$ & Temperature $\left({ }^{\circ} \mathbf{C}\right)$ \\
\hline $6.5-7.8$ & $8.1-8.6$ & $17.3-19.5$ \\
\hline
\end{tabular}

Sturgeon has a complex life cycle and can tolerate various environmental conditions with its strong morphological structure. However, almost all sturgeon species in the world are threatened and their generations have been extincting in today. Hematological and immunological parameters are an effective way to examine physiological and pathological changes in fish. Bahmani et al. (2001) investigated the hematological indices of Persian sturgeon (Acipenser persicus) and beluga (Huso huso) species in different growth stages (1,2 and 6 years old).
They found that erythrocyte count is in the range of $495 \times$ $10^{3}-735 \times 10^{3}$ cells $\mathrm{ml}^{-1}$, leukocyte count is in the range of $31.6 \times 10^{3}-57.7 \times 10^{3}$ cells $\mathrm{ml}^{-1}$, the lymphocyte is in the range of $54.5-67.5 \%$, neutrophil in the range of 22.63 $33.86 \%$, eosinophil in the range of $6.60-13.7 \%$ and monocyte in the range of $0.6-2.25 \%$ for the beluga species. They also found these values for Persian sturgeon as $240 \times 10^{3}-452.5 \times 10^{3}$ cells ml ${ }^{-1}, 13.43 \times 10^{3}-46.48 \times$ $10^{3}$ cells ml-1 $73.25-82.70 \%, 12.3-20 \%, 2.25-6.5 \%$ and $0.2-2.5 \%$, respectively. The erythrocyte, lymphocyte and eosinophil values for beluga were found approximately similar, leukocyte high, monocyte low to the values we detected in our study. For Persian sturgeon, leukocyte, neutrophil and eosinophil values were similar to our findings in our study. Besides, erythrocyte and monocyte values were low, and lymphocyte levels were higher than our study. In a study on hematological reference intervals for cultured shortnose sturgeon (Acipenser brevirostrum), was determined PCV as $26-46 \%$, RBC count as $0.65-$ $1.09 \times 10^{6} / \mu \mathrm{L}, \mathrm{WBC}$ count as $28376-90789 / \mu \mathrm{L}$, large lymphocytes as $2122-10435 / \mu \mathrm{L}$, neutrophils as $3758-$ $33592 / \mu \mathrm{L}$, monocytes as $0-7137 / \mu \mathrm{L}$ and eosinophils as 0 - $1544 / \mu \mathrm{L}$ (the fish ranged from 3- to 5-years old and sexually immature) (Knowles et al., 2006). They reported that these reference intervals values will be beneficial for the early detection, diagnose and monitoring of disease in cultured shortnose sturgeon. Köksal et al. (1999) performed hematological examinations on Siberian sturgeon (Acipenser baeri), they found hematocrit value as $25.28-36.54 \%$, erythrocyte count as $1.14-1.60 \times 10^{6} / \mu \mathrm{L}$, leukocyte count as $19-23 \times 10^{3} / \mu \mathrm{L}$, lymphocyte ratio as $93-95 \%$ and monocyte ratio as $1-2 \%$. Additionally, Ghiasi et al. (2014) examined the hematological values to sterlet sturgeon (Acipenser ruthenus), In the control group it was noticed that RBC count as $1.32 \pm 0.05 \times 10^{5}$, WBC count as $62.3 \pm 7.5 \times 10^{3}$, Hct level as $27.0 \pm 1.3 \%$, lymphocytes as $91.7 \pm 1.4 \%$, neutrophils as $6.8 \pm 1.2 \%$, eosinophils as $0.8 \pm 0.3 \%$ and monocytes as $0.3 \pm 0.1$. Also, Bucur et al. (2009) evaluated hematological parameters of North American sturgeon (Polyodon spathula) in weighing between $200.4 \pm 40.28$ - $1193.7 \pm 57.56 \mathrm{~g}$ cultured in ponds. They detected the hematocrit (Hct) value between 24.5 $41.6 \%$ and the red blood cell count (RBC) between 1.046 $2.252 \times 10^{6} / \mu \mathrm{L}$. In another research, Docan et al. (2017) examined the hematological changes of healthy Russian sturgeon (Acipenser gueldenstaedtii) and they determined $\mathrm{RBC}$ count as $0.45 \pm 0.1 \times 10^{6} / \mathrm{mm}^{3}$, also Hct value as $14.82 \pm 2.73 \%$. In a different study, hematological parameters of Huso huso (5-month-old) in the environment where the environmental salinity was $0 \mathrm{ppt}$ were investigated. Hematological parameters were found as erythrocyte count $86.0 \pm 7.5 \times 10^{4} / \mathrm{mm}^{3}$, leukocyte count $18.2 \pm 2.8 \times 10^{3} / \mathrm{mm}^{3}$, lymphocyte value $57.0 \pm 4.0 \%$, 
neutrophil value $28.6 \pm 3.7 \%$, eosinophil value $13.3 \pm 2.5 \%$ and monocyte $1.0 \pm 1.0 \%$ (Zarejabad et al., 2010). In another study with beluga (Huso huso), Hoseinifar et al. (2011) were found erythrocyte count as $74.16 \pm 16.92 \times$ $10^{4} / \mu \mathrm{L}$, leukocyte count as $20.18 \pm 0.99 \times 10^{3} / \mu \mathrm{L}$, hematocrit value as $19.71 \pm 1.93 \%$, lymphocyte value as $68.51 \pm 2.17 \%$, neutrophil value as $21.96 \pm 2.49 \%$, monocyte value as $4.66 \pm 1.02 \%$ and eosinophil value as $4.41 \pm 1.73 \%$. In addition to Matsche et al. (2014) determined hematological parameters reference intervals of Atlantic sturgeon (Acipenser oxyrinchus oxyrinchus) sampled from three different regions as follows; RBC count $\left(\times 10^{12}\right.$ cells/L) 0.90 - 1.24, hematocrit value (\%) 21 - 26, WBC count $\left(\times 10^{9}\right.$ cells/L) 21.0 - 33.7, lymphocytes $\left(\times 10^{9}\right.$ cells/L) 12.5 - 22.7, neutrophils (x $10^{9}$ cells/L) 1.6 - 7.9, monocytes $\left(\times 10^{9}\right.$ cells/L) $0.3-1.0$ and eosinophils $\left(\times 10^{9}\right.$ cells/L) 0 - 4.6.

The hematocrit values mentioned above by Köksal et al. (1999), Knowles et al. (2006), Bucur et al. (2009), Ghiasi et al. (2014) and Matsche et al. (2014) were found similar to the value we found in our study. The erythrocyte count in our research is similar to the values reported by Köksal et al. (1999), Knowles et al. (2006), Bucur et al. (2009), Zarejabad et al. (2010), Hoseinifar et al. (2011). In terms of leukocyte count, Köksal et al. (1999), Zarejabad et al. (2010) and Hoseinifar et al. (2011) reported close results to our study. Also, Zarejabad et al. (2010) in terms of lymphocyte value and Hoseinifar et al. (2011) in terms of eosinophil and neutrophil value reported similar results to our study. The data similar to our study in terms of monocyte levels were stated by Knowles et al. (2006) and Hoseinifar et al. (2011).

Differences in hematological parameters of fish may be due to varying environmental factors such as changes in the physicochemical parameters of the water, season, water temperature, stock density and photoperiod. Furthermore, many other factors affect hematological parameters in fish such as age, gender, stress, the content of feed, maturity, hypoxia and disease (Affonso et al. 2002; Ruchin 2007; Bucur et al. 2009; Sadati et al. 2011; Nesrin et al. 2018; Duman 2019b; Verep \& Y1ldırım, 2020).

It has been reported that activated macrophages increase IFN- $\gamma$ production which plays an important role in the immune system and also stimulates cytotoxic and suppressor T cells (Mishima et al., 2004). In some studies conducted by Yin et al., (1997), Tafalla et al., (2001) in different types of fish such as catfish (Clarias gariepinus) and turbot (Scophthalmus maximus), they found that the immune response occurred rapidly with increasing TNF- $\alpha$ levels. In a different study with sea bream (Sparus aurata), it has been noticed that in fish stimulated using concanavalin A (Con A) and phorbol myristate acetate (PMA), TNF- $\alpha$ activates macrophages against infection and increases respiratory activity, phagocytosis and nitric oxide production (Mulero \& Meseguer, 1998). To increase the effectiveness of cells participating in the immune response; cytokines, synthesized by stimulated lymphocytes, monocytes and macrophages, and some other somatic cells, regulate immunity and events, including systemic response to cell growth, healing and injury. Bacterial antigens which especially affecting $\mathrm{T}$ lymphocytes, increase the release of cytokines such as IL1, IL-6 and IL-8 (Akdoğan \& Yöntem, 2018). Additionally, Laing et al. (2002) reported that interleukin-8 in rainbow trout (Oncorhynchus mykiss) has important effects on understanding and controlling the processes of inflammation and other immune functions. In fish, cytokines have a direct relationship with microbial interactions and the vital condition of the fish. Also, cytokines are one of the important indicators of nonspecific immune response and they are considered to be important immune-activators involved in antigenic stimulation.

\section{CONCLUSION}

It is thought that hematological and immunological reference intervals are important in terms of early diagnosis, detection of diseases, treating diseases and reducing mortality in sturgeon culture. The first time to determine the reference values of these parameters is important, which are considered as indicators of fish health and stress fact for the Russian sturgeon. More research is recommended on the biology, physiology and development of these fish, which are very valuable due to their caviar.

\section{ACKNOWLEDGEMENTS}

This study was supported by Cukurova University Scientific Research Projects Unit. Project Number: FBA2018-11062.

\section{REFERENCES}

Affonso, E.G., Polez, V.L.P., Correa, C.F., Mazon, A.F., Araujo, M.R.R., Moraes, G. \& Rantin, F.T. (2002). Blood parameters and metabolites in the teleost fish Colossoma macropomum exposed to sulfide or hypoxia. Comp Biochem Physiol C Toxicol Pharmacol, 133, 375-382. DOI: 10.1016/S1532-0456(02)00127-8

Akdoğan, M. \& Yöntem, M. (2018). Sitokinler. Online Türk Sağllk Bilimleri Dergisi, 3(1), 36-45. DOI: 10.26453/otjhs.350321

Alyakrinskyaya, I.O. \& Dolgova, S.N. (1984). Hematological features of young sturgeons. Vopr Ikhtiol, 4, 135-139.

Bahmani, M. (1998). Phylogenic and systematic study on sturgeons. Iranian scientific fisheries journal, 7(2), 9-30. 
Bahmani, M. (1999). Application of biological characteristics of fish in aquaculture related to reproduction physiology. Eighth Iranian National Conference of Biology. 31 August - 2 September. Kermanshah, Iran (in Persian).

Baker, D.W., Wood, A.M., Litvak, M.K. \& Kieffer, J.D. (2005). Haematology of juvenile Acipenser oxyrinchus and Acipenser brevirostrum at rest and following forced activity. Journal of Fish Biology, 66(1), 208-221. DOI: 10.1111/j.00221112.2005.00595.x

Bahmani, M., Kazemi, R. \& Donskaya, P. (2001). A comparative study of some hematological features in young reared sturgeons (Acipenser persicus and Huso huso). Fish Physiology and Biochemistry, 24(2), 135-140. DOI: 10.1023/A:1011911019155

Blaxhall, P.C. (1972). The haematological assessment of the health of freshwater fish: a review of selected literature. J. Fish Biol., 4, 593-604.

Blaxhall, P.C. \& Daisley, K.W. (1973). Routine haematological methods for use with fish blood. J. Fish Biol., 5, 771-781.

Bucur, C., Radu, D., Marica, N., Oprea, D. \& Stancioiu, S. (2009). Preliminary hematologic studies on Polyodon spathula (Walbaum, 1792) reared in controlled system. Annals of the University Dunarea de Jos of Galati Fascicle VI--Food Technology, 3(33), 62-69.

Cataldi, E., Di Marco, P., Mandich, A. \& Cataudella, S. (1998). Serum parameters of Adriatic sturgeon Acipenser naccarii (Pisces: Acipenseriformes): effects of temperature and stress. Comparative Biochemistry and Physiology Part A: Molecular \& Integrative Physiology, 121(4), 351-354.

Chebanov, M.S. \& Galich, E.V. (2011). Sturgeon hatchery manual. FAO Fisheries and Aquaculture Technical Paper. Ankara, Turkey.

Docan, A., Grecu, I., Creţu, M., Antache, A. \& Dediu, L. (2017). Haematological and serum biochemical changes associated with bacteriological infection in Acipenser gueldenstaedtii reared in intensive condition. Lucrări Științifice-Universitatea de Științe Agricole și Medicină Veterinară, Seria Zootehnie, 67, 104-109.

Duman, S. \& Şahan, A. (2018). Some hematological and non-specific immune responses of rosehip (Rosa canina)-Fed Russian Sturgeon (Acipenser gueldenstaedtii Brandt \& Ratzeburg, 1833) to Mycobacterium salmoniphilum. Brazilian Archives of Biology and Technology, 61. DOI: 10.1590/1678-4324-2018180283

Duman, S. (2019a). The effect of anesthetic (2phenoxyethanol) application on some biochemical and hematological parameters in Russian sturgeon (Acipenser gueldenstaedtii) and Siberian sturgeon (Acipenser baerii) during transport. Turkish Journal of Veterinary and Animal Sciences, 43(6), 825-833. DOI: 10.3906/vet-1812-96
Duman, S. (2019b). Grading the Occurrence of Scoliosis Seen in Siberian Sturgeon (Acipenser baerii Brandt, 1869). Journal of Anatolian Environmental and Animal Sciences, 4(2), 145150. DOI: 10.35229/jaes.552819

Düzgüneş, D., Kesici, T. \& Gürbüz, F. (1983). İstatistik metodlart-I. A.Ü. Ziraat Fakültesi Yayınları, Ankara, Turkey.

Fujimaki, Y. \& Isoda, M. (1990). Fine-structural study of leucocytes in the goldfish, Carassius auratus. $J$. Fish Biol. 36, 821-831. DOI: 10.1111/j.10958649.1990.tb05630.x

Ghiasi, S., Falahatkar, B., Dabrowski, K., Abasalizadeh, A. \& Arslan, M. (2014). Effect of thiamine injection on growth performance, hematology and germinal vesicle migration in sterlet sturgeon Acipenser ruthenus L. Aquaculture International, 22(5), 1563-1576. DOI: $10.1007 / \mathrm{s} 10499-014-9765-7$

Hoseinifar, S.H., Mirvaghefi, A., Merrifield, D.L., Amiri, B.M., Yelghi, S. \& Bastami, K.D. (2011). The study of some haematological and serum biochemical parameters of juvenile beluga (Huso huso) fed oligofructose. Fish Physiology and Biochemistry, 37(1), 91-96. DOI: 10.1007/s10695-010-9420-9

Houston, J.B. \& Carlile, D.J. (1997). Incorporation of in vitro drug metabolism data into physiologicallybased pharmacokinetic models. Toxicology in Vitro, 11(5), 473-478. DOI: 10.1016/S08872333(97)00056-8

Knowles, S., Hrubec, T.C., Smith, S.A. \& Bakal, R.S. (2006). Hematology and plasma chemistry reference intervals for cultured shortnose sturgeon (Acipenser brevirostrum). Veterinary Clinical Pathology, 35(4), 434-440. DOI: 10.1111/j.1939165X.2006.tb00160.x

Kocabatmaz, M. \& Ekingen, G. (1984). Standardization of haematological methods and taking blood from various fish species. J. of Nature Sci. 2, 149-159.

Laing, K.J., Zou, J.J., Wang, T., Bols, N., Hirono, I., Aoki, T. \& Secombes, C.J. (2002). Identification and analysis of an interleukin 8-like molecule in rainbow trout Oncorhynchus mykiss. Developmental \& Comparative Immunology, 26(5), 433-444. DOI: 10.1016/S0145$305 X(01) 00092-1$

Matsche, M.A., Arnold, J., Jenkins, E., Townsend, H. \& Rosemary, K. (2014). Determination of hematology and plasma chemistry reference intervals for 3 populations of captive Atlantic sturgeon (Acipenser oxyrinchus oxyrinchus). Veterinary Clinical Pathology, 43(3), 387-396. DOI: $10.1111 /$ vcp.12174

Mishima, S., Saito, K., Maruyama, H., Inoue, M., Yamashita, T., Ishida, T. \& Gu, Y. (2004). Antioxidant and immuno-enhancing effects of Echinacea purpurea. Biological and Pharmaceutical Bulletin, 27(7), 1004-1009. DOI: 10.1248/bpb.27.1004 
Mulero, V. \& Meseguer, J. (1998). Functional characterisation of a macrophage-activating factor produced by leucocytes of gilthead seabream (Sparus aurata L.). Fish \& Shellfish Immunology, $\quad 8(2), \quad 143-156 . \quad$ DOI: 10.1006/fsim.1997.0127

Emre, N., Güroy, D., Yalım, F.B., Emre, Y., Güroy, B., Mantoğlu, S. \& Karadal, O. (2018). Growth Performance, Body Composition, Haematological and Serum Parameters to Fish Meal Replacement by Soybean Meal and Cottonseed Meal in Russian Sturgeon (Acipenser gueldenstaedtii). Journal of Limnology and Freshwater Fisheries Research, 4(3), 169-176. DOI: 10.17216/limnofish.460773

Nussey, G., Van Vuren, J.H.J. \& Du Preez, H.H. (1995). Effect of copper on the haematology and osmoregulation of the Mozambique tilapia, Oreochromis mossambicus (Cichlidae). Comparative Biochemistry and Physiology Part C: Pharmacology, Toxicology and Endocrinology, 111(3), 369-380. DOI: 10.1016/0742-8413(95)00063-1

Ruchin, A.B. (2007). Effect of photoperiod on growth, physiologica and hematological indices of juvenile Siberian sturgeon Acipenser baerii. Biology Bulletin. 34, 583-589. DOI: 10.1134/S1062359007060088

Sadati, M.A.Y., Pourkazemi, M., Shakurian, M., Hasani, M.H.S., Pourali, H.R., Pourasaadi, M. \& Yousefi, A. (2011). Effects of daily temperature fluctuations on growth and hematology of juvenile Acipenser baerii. Journal of Applied Ichthyology, 27(2), 591-594. DOI: 10.1111/j.1439-0426.2011.01667.x

Stolen, S.J., Fletcher, T.C., Rowley, A.F., Zelikoff, J.T., Kaattari, S.L. \& Smith, S.A. (1994). Techniques in fish immunology. Fish immunology technical communications. 1st ed. Virginia-Maryland, USA.

Şahan, A., Duman, S., Çolak, S. Ö., Çinar, E. \& Bilgin, R. (2017). Determination of some hematological and non-specific immune defences, oxidative stress and histopathological status in rainbow trout (Oncorhynchus mykiss) fed rosehip (Rosa canina) to Yersinia ruckeri. Turkish Journal of Fisheries and Aquatic Sciences, 17(1), 91-100. DOI: 10.4194/1303-2712-v17_1_11

Tafalla, C., Figueras, A. \& Novoa, B. (2001). Viral hemorrhagic septicemia virus alters turbot Scophthalmus maximus macrophage nitric oxide production. Diseases of Aquatic Organisms, 47(2), 101-107. DOI: 10.3354/dao047101

Tavakoli, M., Fazli, H., Moghim, M., Khoshghalb, M.R., Valinasab, T. \& Abdolmaleki, S. (2019). Population ecological parameters and stock assessment of Russian sturgeon Acipenser gueldenstaedti Brandt \& Ratzeburg, 1833 in the Southern Caspian Sea. Journal of Applied Ichthyology, 35(1), 378-386. DOI: 10.1111/jai.13730
Trenzado, C.E., Carrick, T.R. \& Pottinger, T.G. (2003). Divergence of endocrine and metabolic responses to stress in two rainbow trout lines selected for differing cortisol responsiveness to stress. General and Comparative Endocrinology, 133(3), 332-340. DOI: 10.1016/S00166480(03)00191-6

Van Vuren, J.H. (1986). The effects of toxicants on the haematology of Labeo umbratus (Teleostei: Cyprinidae). Comparative Biochemistry and Physiology. C, Comparative Pharmacology and Toxicology, 83(1), 155.

Verep, B. \& Yıldırım, H. (2020). Lepistes Balıklarında Bazı Herbisidlerin Akut Toksik Etkisinin Araştırılması. Journal of Anatolian Environmental and Animal Sciences, 5(1), 106114. DOI: $10.35229 /$ jaes.708014

Voller, A., Bartlett, A. \& Bidwell, D.E. (1978). Enzyme immunoassays with special reference to ELISA techniques. Journal of Clinical Pathology, 31(6), 507-520.

Yin, Z., Lam, T.J. \& Sin, Y.M. (1997). Cytokinemediated antimicrobial immune response of catfish, Clarias gariepinus, as a defence against Aeromonas hydrophila. Fish \& Shellfish Immunology, 7(2), 93-104.

Zarejabad, A.M., Jalali, M.A., Sudagar, M. \& Pouralimotlagh, S. (2010). Hematology of great sturgeon (Huso huso Linnaeus, 1758) juvenile exposed to brackish water environment. Fish Physiology and Biochemistry, 36(3), 655-659. DOI: $10.1007 / \mathrm{s} 10695-009-9339-1$ 